\title{
The Epigone's Embrace, Part II: C. Wright Mills and the New Left
}

John H. Summers-Boston College

Charles Wright Mills was laid in a lonesome corner of Oak Hill Cemetery, Nyack, New York, the last week in March 1962. A Roman Catholic service was performed at a nearby church at the request of his mother, Frances Mills. The International Fellowship of Reconciliation conducted a Quaker service over the grave. A grey tombstone marked the ground. Etched in the marble was an aphorism taken from his last book, The Marxists: "I have tried to be objective. I do not claim to be detached." He was forty-five.

Mills left behind a remarkable legacy. Just before he died, Ballantine Books printed 56,000 copies of his pamphlet, The Causes of World War Three. ${ }^{1}$ The Marxists, published the week after, began brisk sales to college students in the rich countries even as Listen, Yankee: The Revolution in Cuba, was selling in Angola, Ethiopia, Haiti, and Laos. ${ }^{2}$ White Collar, The Power Elite, and The Sociological Imagination, the books that had made Mills the most widely read American sociologist in the world, were sowing discontent from New York to Tokyo. ${ }^{3}$

The complete bibliography listed seven books under Mills's name, four more collaborative volumes, and approximately 250 briefer pieces. ${ }^{4}$ There was much more besides. In the office in Columbia University's Hamilton Hall, where he had taught since 1945, the sprawling manuscript of The Cultural Apparatus lay alongside research for a multivolume work in comparative sociology, plus 350 pages of Soviet Journal and Contacting the Enemy. The archive later deposited at the University of Texas filled 88 boxes. Other materials troved in his home in West Nyack included diaries, letters, lectures, plans for work, transcripts, autobiographies, syllabi, and clippings, in addition to hours and hours of dictation recorded on reel-to-reel tapes. It was a large life to lose. The evidence was everywhere.

Mills remains today, more than 45 years after his death, a pivotal figure. A recent poll of the International Sociological Association ranked The Sociological Imagination the second most influential book in twentieth-century sociology, behind only Max Weber's Economy and Society. ${ }^{5}$ American historians have been concerned to understand his influence as a practitioner of pragmatic cultural criticism and as a radical political leader. ${ }^{6}$ In 2004, writing in Playboy, Arthur Schlesinger Jr., identified The Power Elite as the leading alternative to the liberal theory of power in America and renewed his frequent attacks on the book and its author. ${ }^{7}$ Todd 
Gitlin has pronounced Mills "the most inspiring sociologist of the second half of the twentieth century" and recommended him for "a new start for intellectual life on the left." ${ }^{8}$

Other examples of his continuing importance are scattered in the winds. In Acbieving Our Country, Richard Rorty faulted the "Mills-Lasch thesis" for misleading generations of Americans on the threat of international communism." Robert Bork, in Slouching Towards Gomorrah, agreed with Rorty's assessment from another direction, for different reasons. Bork ranged Mills with Elvis Presley, James Dean, and Jack Kerouac, "harbingers of a new culture that would shortly burst upon us and sweep us into a different country." ${ }^{10}$ Far from the eccentric or isolated figure, Mills was a representative man, says Immanuel Wallerstein, a former student and colleague who carries on the critical sprit of his work. "If Mills failed, so have we all. If Mills is still relevant, so are we all. His ambiguities, his anxieties, his idealism are ours, in short, his biography is our collective biography."11

This article, the sequel to "The Epigone's Embrace: Irving Louis Horowitz on C. Wright Mills," establishes terms for a large-scale reassessment of Mills's legacy. ${ }^{12}$ Here, as before, I am concerned less with advancing an independent interpretation of his social thought than with showing how and why various factions swirling around him after his death discouraged the possibility of an independent interpretation in the first place, how Mills's biography, in short, became part of the political and cultural struggles of the 1960s. Since the evidential basis of received opinion about him is still nothing but a maw of apocrypha, partial truth, and provincial falsification, I have tried to supply complete, accurate citations to the extraordinary range of influence he commanded after his sudden death in 1962, much wider, indeed, than the received opinion indicates. These sources cast Mills's story against a background at once social, political, intellectual, and international. They lay a fresh research trail around the many institutions, personalities, places, and movements through which he passed.

"Mills's legacy is a summons, no secure possession," Hans Gerth wrote in a eulogy for his former student, collaborator, and friend. In magazines such as New University Thought, Liberation, New Politics, Evergreen Review, Root and Branch, Ramparts, and Studies on the Left, a new generation of students and activists heeded the summons. Mills appeared in them as a political leader who perceived assumptions, exposed limits, clarified problems, and demanded solutions; as a writer who provoked them on multiple registers of experience; as a sociologist who taught that understanding the power of human character meant understanding the society that made certain characters possible and necessary. As the editors of Our Generation Against Nuclear War wrote in the summer 1962, "Wright Mills taught that our actions do in fact matter, and that we have choices presented to us every dayimportant choices—and we must accept their challenge and act accordingly."

Lawrence Ferlinghetti turned him into a symbol of countercultural cool 
in "A Parade Tirade (for C. Wright Mills)," a free-form poem appearing in Liberation in December 1962. "The America of the american legion isn't ours," Ferlinghetti wrote, mocking the "big phoney scene, having nothing to do with our america." "14 The two-Americas thesis, old as America itself, shot to the center of the radicalism that grew up around Mills's example. In Desert Solitaire (1968) the anarchist writer Edward Abbey chronicled a secession from "the clamor and filth and confusion of the cultural apparatus" borrowing a key phrase. ${ }^{15}$ In the San Francisco Chronicle, the music columnist Ralph Gleason said "Mills had the effect on his colleagues that Charlie Parker had on the saxophone section of the Guy Lombardo band. He had the jazz mind." 16 Theodore Roszak compared him to Emile Zola, dramatist for the underclass. ${ }^{17}$ Even Norman Mailer, so jealous and so inventive a maker of rhetoric, borrowed "the power elite" when the time came in The Armies of the Night (1968). ${ }^{18}$

Intellectuals across Europe and Latin America hailed Mills as the representative of an indigenous American radicalism engulfed by the Cold War. The United States lost "a mentor and distinguished representative," said the editors of El Mundo, in Havana. ${ }^{19}$ The Cuba Youth Union of Writers and Artists sent a sympathy message to the funeral. Carlos Fuentes called him "a man of action" and a "valorous knight of the truth" in Politica, not long before the Mexican government forced the magazine out of existence. ${ }^{20}$ Fuentes dedicated his first international bestseller, The Death of Artemio Cruz (1962), "To C. Wright Mills. True Voice of the United States of America. Friend and companion in Latin America's stru goge."

The list of friends and correspondents generated by Mills's travels in the 1950s became, in the 1960s, a first-class roster and record book of radical thinking, a rallying point in the genealogy of the New Left. He was the elder figure they all knew in common. "He served in himself as a hyphen, joining the dissenting intellectuals of two conformist worlds," E.P. Thompson wrote in $1963 .{ }^{21}$ Thompson praised him as a pioneer in using paperback books as counter-media and compared him to William Morris, no casual comparison in light of the fact that Thompson was the author of a 900-page homage on the man. But it was Mills's attempt to throw open the Cold War to new voices that called out his highest praise. "His star stood above the ideological no-man's land of orthodox emplacements of West and East, flashing urgent humanist messages. If we couldn't always follow it, we always stopped to take bearings." 22

At home, a corresponding movement for "radical sociology," the first in the history of professional sociology in the United States, widened the cracks he had made. Maurice Stein and Arthur Vidich, editors of the influential Sociology on Trial (1963), reprinted a chapter from The Sociological Imagination and dedicated the book to him. ${ }^{23}$ G. William Domhoff pursued the power elite thesis in Who Rules America? (1976) and The Higher Circles (1970). Membership in the American Sociological Association more than doubled over the decade, and the radicals signalled solidarity at overcrowded, raucous conventions by pinning " $\mathrm{C}$. Wright Mills 
Lives" buttons to their suits. Apocrypha circulated about his academic career. In The Coming Crisis of Western Sociology (1970) Alvin Gouldner asserted that he had never made it to full professor. ${ }^{24}$ A German translator of Character and Social Structure claimed he had lost his professorship in the McCarthy purges. Then a Yugoslavian journal of social science repeated the error, adding that his Marxism had caused his dismissal. ${ }^{25}$ Columbia University students traded a rumour according to which his colleagues and adversaries Paul Lazarsfeld and Robert Merton had conspired to murder him in the 116th Street subway station. ${ }^{26}$

Dusky Lee Smith flunked out of high school and would have quit college were it not for The Power Elite. Even before Smith completed his doctorate at the State University of New York, Buffalo, he mustered confidence enough to fire off intemperate attacks on the sociological establishment. ${ }^{27}$ "I know I will never be as great a man in the intellectual world as your son," Smith wrote in 1965, after making a pilgrimage to Frances Mills in San Antonio, "but I know I will try to follow in his footsteps to the best of my ability. (And in my own way). But I do find many similarities between Charles Wright and my self in many areas." Mixing flattery of Frances Mills with promises to slay her son's critics, Smith's letter bared the ressentiment underlying radical sociology in these heady years. ${ }^{28}$

Mills's reputation carried none of the metaphysical guilt of a communist past and at the same time exemplified unbroken radical commitment. Entrenched representatives of the political Left saw the entailments of his stature all too clearly. "Is the recognition that Marx was a great man and made lasting contributions to human thought the basic criterion for working in 'the tradition of Marx'?" asked the official journal of the American Communist Party, in a sour review of The Marxists. "No, we are sorry, we cannot go along, for this is a stretch-hose so elastic that any foot could wear it." 29 Others went along in relief and gratitude. Jonah Raskin, a Columbia University student and activist, "read The Power Elite when it first came out, and was delighted that somebody who wasn't a communist or an old school Marxist had come out and pointed to the powers-that-be in the USA." ${ }^{30}$ Morton Horwitz read the book in the second semester of his junior year at the City College of New York. Horwitz had studied Marx in high school; his uncle was treasurer of the Manhattan Communist Party. "But I had never read anything like The Power Elite." ${ }^{11}$ After 1956, Horwitz's uncle fell into embarrassed silence while he was able to continue to think and talk radically about politics.

Mills's criticism of leftist cant and dogma made his work available to rival groups within the new constellation. Stokely Carmichael read The Power Elite in a study group at Howard University. ${ }^{32}$ Soon after, he went south to participate in the Congress of Racial Equality's "Freedom Rides." The decision earned him jail sentence in the Parchmann State Reformatory, in Mississippi. Part of the 49 days he spent in prison he spent reading more Mills. "You know how dumb them crackers are?" he told a Village Voice reporter after his release. "In jail they took away all my books_-stuff by DuBois, King, Camus. But they let me keep Mills's book 
about Castro, Listen, Yankee, because they thought it was against Northern agitators"33 Carmichael's odyssey from the Student Nonviolent Coordinating Committee to the Black Panthers, from nonviolent disobedience to guerrilla warfare, produced one of the decade's most hotly debated books, Black Power (1967). Its main idea, "institutionalized racism," satisfied Mills's exhortation to locate personal troubles in the framework of public structures, though its whirlwind of separatist rhetoric drained off the analytical potential of the power elite thesis and left a residue of propaganda.

The most astute critic of "black power," Harold Cruse, found inspiration in another corner of Mills's work. Cruse resigned his membership in the Communist Party in 1952, dissatisfied with the unreflexive form of Marxism it sheltered, and grew convinced of its irrelevance to the special problems of American blacks. In 1965 and 1966, in a course at the Black Arts Repertory School in Harlem, he made Mills a prominent part of the curriculum. The following year, The Crisis of the Negro Intellectual acknowledged the largeness of the debt. "For me, the emergence of C. Wright Mills, with his critique of the policies, dogmas, and vanities of the old Marxist leftwing, was a landmark in American social theory," Cruse wrote. ${ }^{34}$ He urged black intellectuals to reject the roles of guerrilla warrior, civil rights spokesman, and party operative and instead to seek influence as intellectuals working toward a biracial cultural democracy. He recommended Mills as the best place to begin. The "cultural apparatus" offered a "new method for a new radical criticism of American society," since it concentrated attention on the social functions of communication machines from which blacks had been shut out. Mills had not addressed himself to race, but neither had black theoreticians engaged him in their problems, crippled as they had been by the Marxist distrust of mass society theory. If they looked at him anew, they would find a model that "contained the seeds of a Negro-White alliance of a new type." ${ }_{35}$

The fluency of Mills's vocabulary was such that even single examples of his writings encouraged different temperaments and projects. Thus Abbie Hoffman, the American prankster, and Gabriel Zaid, the Mexican poet, had little in common other than a shared debt to an essay titled "The Cultural Apparatus." Zaid was writing poetry when he encountered it in translation. From its daring terms and definitions he forged his own distinctive cultural criticism. ${ }^{36}$ Abbie Hoffman read the essay early in the decade, and soon made it the "theoretical basis of what was to come." What was to come was a politics of culture that aimed, if not to repossess "the cultural apparatus," then at least to bring it into the slums and streets, to expose it to counter-symbols that would disclose its underlying absurdity. Hoffman and fifteen of his fellow anarchists and hippies entered the gallery of the New York Stock Exchange, tossed three hundred dollar bills over the railing, and looked on as the stock brokers scrambled for money fluttering from the sky. Hoffman described this sort of gesture as "image war" or "symbol war." It was as reasonable an adaptation of Mills's sociology of culture as Zaid's 
soberminded contributions to Letras Libres.

Christopher Lasch made use of the "The Cultural Apparatus" in The New Radicalism in America (1965), where he advanced a sociology of literary success that read as a close paraphrase of Mills. ${ }^{38}$ Although Lasch had not met him at Columbia, where he attended graduate school in History in the late 1950s, the essays collected in The Agony of the American Left (1969) and The World of Nations (1974) moved into the "no-man's land" between politics and culture, power and conscience, confrontation and withdrawal. Lasch did more than anybody to reconstruct indigenous forms of critical thought with the tools Mills had sharpened. His mature work, Haven in a Heartless World (1977), The Culture of Narcissism (1979), and The Minimal Self (1984) were sophisticated attempts to delineate the changing relations between personality structure and advanced capitalism, to connect "private troubles" with "public issues," foreign policy with domestic, family life with government policy, from a position outside parties, cliques, classes, movements, and nations.

While Hoffman carried Mills's ideas into the New York Stock Exchange and Lasch carried them into the New York Review of Books, Dave Meggyesy carried them into the locker-room of the St. Louis Cardinals. Meggyesy, raised on a pig farm in Ohio, had every reason to be grateful to football. He made All-American at Syracuse University, then joined the Cardinals, and eventually started as linebacker.

By this time, however, Meggyesy had begun to ask questions that his friends and team-mates found discomfiting. In January 1966, he enrolled in a graduate course in education in Washington University, St. Louis; it was there that he discovered The Sociological Imagination. "It influenced my thinking more than any other book up to that moment," he remembered in his shattering autobiography, Out of Their League (1970). ${ }^{39}$ Meggyesy reported the racism, fraud, and brutality he had witnessed during his football career, arguing against the assumption that immoralities were isolated events. Meggyesy called them functional parts of a partially organized system according to which bureaucratic and commercial interests corrupted and exploited all social values in their path. Ever since high school his coaches had barked that football was "character-building." The Sociological Imagination showed him how to turn this platitude on its head. In describing the qualities of human character recruited and formed by the professional football teams, Meggyesy paraded before an American public, a public used to glorifying its athletes, a roster of sadists, gamblers, drug addicts, cripples, and paymasters united by a puerile fear of losing. Asked by the New York Times how, then, he expected to put across his message, Meggyesy pleaded patience. "People don't see the whole process; they have to learn to make connections, to make the hookup between personal biography and history, like C. Wright Mills said." ${ }^{40}$

Then there were the leaders of the new Students for a Democratic Society (SDS) — the old SDS being an affiliate of the League for Industrial Democracy, 
where ex-Marxists, liberals, and social democrats mingled in postures of disbelief. ${ }^{41}$ The interest in Mills on the part of the SDS new leadership was distinguished by its personal intensity. Outstanding representatives of their generation, students in the country's best universities, they read the "Letter to the New Left" and felt anointed. Mills once said that those who read him in the right spirit "often come to feel as if suddenly awakened in a house in which they had only supposed themselves to be familiar." ${ }^{42}$ This became true, literally, in the experience of Todd Gitlin, Richard Flacks, Bob Ross, and Tom Hayden, whose initial encounters with his books first crystallized the unease they felt within the institutions that had raised and reared them, then inducted them into a brotherhood of radical striving. On the second day of the Bay of Pigs, these four staged the first campus demonstrations in the country. They looked to Mills like light behind the eyes and became, through him, spiritual descendents of Turgenev's Bazarov and London's Martin Eden, sons without fathers, non-party revolutionaries, the latest breed in a long line of "new men" who stole into mass society in the nineteenth century in Europe and America, and played havoc ever after.

Gitlin first read him in the autumn 1960. He was a student at Harvard. The anti-nuclear group, SANE, held a rally at the Boston Garden, where Gitlin picked up a booklet that contained an excerpt from The Causes of World War Three. "I read the book and it knocked me out," he says. ${ }^{43}$ After debating with student friends over lunch, he put his thoughts in an essay and sent it to The Tocsin, a campus newsletter founded to encourage disarmament initiatives. "Can We Trust the Russians?" was a close paraphrase of The Causes of World War Three. Gitlin argued, as Mills had argued, that the Soviets believed they could win a peaceful competition in culture and economy, that they recognized the unique danger posed by the new weaponry of war, that there was not, in any case, any meaningful alternative to negotiation.

"Can We Trust the Russians?" ran in the December 16, 1960, issue of The Toscin. During the Christmas intersession, Gitlin went home and brandished his new radicalism, "and my parents accused me of wrong-headedness for getting involved in politics." Gitlin's father, a Democrat, upheld the party's view of foreign affairs. "I threw Mills's arguments at my father and noted with satisfaction that he hadn't a convincing comeback." ${ }^{\prime 4}$ Gitlin spent the summer of 1962 studying defense policy at the Peace Research Initiative in Washington, DC. The next year he was president of SDS. For the remainder of the decade he filled underground magazines with defenses of The Power Elite against Talcott Parsons, David Riesman, Daniel Bell, and Robert Dahl. In 1966, he published a poem, "Mills the Cat," so named because it was "almost red." 45

Richard Flacks encountered him as a graduate student at the University of Michigan. The Sociological Imagination "hit me like a truck," he said, echoing Gitlin's experience of sudden conversion. "I thought that book was written for me." Flacks completed his doctorate in sociology at the University of Michigan 
and joined the faculty at the University of Chicago. In 1966, he and his wife named their first child Charles Wright Flacks. ${ }^{46}$ Bob Ross encountered The Power Elite as a student in a political science honours seminar at Michigan. The professor, expecting to discredit the book, made the students check the footnotes. On Ross the lesson had the opposite effect.

Gitlin said Mills "knocked me out." Flacks said Mills "hit me like a truck." Bob Ross "was seized by the power of Mills's language, by his craft, by his anger, by the power of the powerful he depicted." Ross began reading The Power Elite on a winter evening, and went all through the night. "Ann Arbor was cold and gray that morning, and I wandered the streets weeping. They were so strong; we were so small. How could we ever call them to account?" 47 He switched majors from political science to sociology. In 1963, he wrote a senior honours thesis on Mills: "The Power and the Intellect." After a stint in London, where he studied with Mills's friend Ralph Miliband, he followed Flacks to Chicago and entered graduate school in sociology. Mills was "the chief reason" for the decision. ${ }^{48}$

Among these enthusiasts one stood out. Tom Hayden was a rising senior at the University of Michigan and the editor of the college newspaper when Flacks recommended that he read Mills. This was the summer of 1960. Hayden had gone to Los Angeles to report on the Democratic National Convention. He had spent some time in Berkeley, and he had undertaken fact-finding incursions into the South. The issues that welled up from his travels-civil rights, free speech-exposed him to the ambiguities in the professional liberalism he had inherited from his father, an accountant for Chrysler. "As I poured through Mills, I saw an image of my father, proud in his starched white collar, occupying his accountant's niche above the union work force and below the real decision makers, penciling in numbers by day, drinking in front of the television at night, muttering about the world to no one in particular." ${ }^{49}$

The more young Hayden learned about Mills the more he thought he recognized aspects of himself. Both had grown up as Irish Catholics misbegotten into areas dominated by Protestants, in homes dominated by their mothers. Both had rejected their mother's faith while still in high school. Both suppressed feminine sensitivities behind the roar of their motorcycles. Hayden's eye-catching journalism had endeared him to Flacks and others at Michigan, and as he read Mills he decided that politics was to be his proving ground, just as it had been Mills's. At the end of 1960 he published a "Letter to the New (Young) Left" in which he too dismissed the "NATO intellects" and stressed personal commitment. ${ }^{50}$ By the time he met a centre in his absorption, he envisioned Mills as a combination of James Dean and AlbertCamus, "a model of a new kind of committed intellectual.",

Hayden graduated from Michigan in June 1961. Persuaded to join SDS by Bob Ross (and others), he moved to Atlanta to report on the struggle for civil rights. Over the next year, he solidified his status in the student movement by drafting a manifesto for the new SDS, a statement of belief that was to lay the 
basis for discussion the following summer, when the membership of the fledgling new group was to convene at Port Huron, Michigan, for a conference. Hayden finished one complete draft when Mills's death pulled him up short. "I remember my whole body hardening when I came upon the obituary in The New York Times. It was as though his own powerful physical system, thrown unrelentingly into the grinding process of his mission, broke down in desperation and futility. For me, it symbolized the shattering isolation and collapse of American radicalism against a fundamentally overpowering system." ${ }^{52}$ Three months later, Hayden, Ross, and Flacks joined with 57 students, activists, and intellectuals at the FDR Labor Center in Port Huron. They arranged themselves into small groups ("something like those which C. Wright Mills imagined") out of which emerged the most widely circulated leftwing manifesto of the $1960 \mathrm{~s}^{53}$

Hayden enrolled in graduate school at the University of Michigan, where he wrote, in 1963 and 1964, a Master's thesis on Mills: "Radical Nomad." The introduction characterized it as "a frankly partisan work, which begins and ends with an enormous sympathy for the intellectual and political struggle of C. Wright Mills." ${ }^{54}$ The thesis was not uncritical. Hayden observed that Mills's portrayal of the "overdeveloped society" overlooked those areas of the country in which the actual problem was underdevelopment. Too little was said in Mills's books about the special problems of the poor, especially of poor blacks. Nonetheless, Hayden held, the radically sociological conception of power in these books described political reality in the South far better than the liberal theory of balance. What forces had countervailed against the fraud and violence perpetrated against southern blacks over the last century? Hayden ended the thesis in a reverent key. He wrote an imaginary dialogue as if Mills's ghost was speaking through him, illuminating the dark and lonely path ahead. In the summer 1964, he threw himself back into the world, "to see whether I could carry his lessons into practice, and whether practice might produce further evidence of its own." ${ }_{55}$

Students for a Democratic Society grew into the largest and most important New Left student organization in America. Mills's influence continued in word and in deed. Hayden moved to Newark to work on SDS's Economic Research and Action Project (ERAP), a community organizing project designed to repair links between intellectuals and poor people and to establish the political value of local action against the oligarchy of power. And SDS actively diffused his writings, printing mimeographs of the "Letter to the New Left" in great quantities. Of 25 new recruits interviewed by a Village Voice reporter in 1965, none could claim to have read Rosa Luxemburg, Max Weber, John Dewey, or John Stuart Mill. A few said they had read Vladimir Lenin, Leon Trotsky, or Karl Marx. Half had read Paul Goodman, Herbert Marcuse, or Frantz Fanon. Almost everybody had read Mills. ${ }^{56}$

Enemies, equally attuned to the manysided significance of Mills's legacy, fired 
from every direction in the months and years after his death. In Washington, Senator Thomas Dodd subjected his associates in the Fair Play for Cuba Committee to sharp questioning at a hearing of the Judiciary Committee. ${ }^{57}$ In London, Labour MP Anthony Crosland complained to the BBC about the diffusion of his ideas in Britain. "Many people on the left see America as the arch-capitalist country dominated by a power elite of big industrialists, Wall Street bankers, military men and all the rest of it. And so, since they are anti-capitalist, they are inevitably anti-American. Personally, I think that this picture of America is terribly exaggerated. I do not think America is run in this crude way by a capitalistic power elite." 58 In Rockland County, a group calling itself "True Friends of the Library" petitioned "citizens and taxpayers" to withdraw his books from the New City Public Library and to ban them thereafter. A meeting was held for the purpose on 18 February 1963.

Opponents of the new radicals treated their audacity as a psychological disorder. Arnold Rose, president of the American Sociological Association, wrote The Power Structure (1967) because, he said, "The Power Elite has become almost a bible for a younger generation of 'new Leftists' who have a deep-seated need to attack a society which they fail to understand." 59 Irving Howe assessed Mills's enthusiasts as a claque of desperadoes whose stylized political gestures served chiefly to call attention to the loneliness of the over-organized society. For their interest in Cuba, for their diffidence toward anticommunism, Howe reprimanded and on due occasion humiliated the new radicals. Trenchant though his criticisms were, his most important points were available elsewhere, in the writings of Christopher Lasch, for example. What distinguished Howe's stance was the absolutism in which he couched it. The same tone he had used in condemning The Causes of World War Three he now turned against its newest wave of readers. "In his last years," Howe wrote in 1963, "Mills became the idol of an international political tendency, the authoritarian left. The sad truth is that he deserved the admirers he won." 60

The fraternity Mills had enjoyed from his liberal friends in the 1950s, when he could be expected to do little harm, vanished with the return to liberalism to the executive branch of government. Charles Frankel had lived alongside him as friend and neighbour, had co-taught a seminar with him at Columbia College, had spoken judiciously at a Commemorative Meeting held for him in Harkness Theater. "He let you know him, and just as much to the point, he forced you to come to terms with yourself, to learn about yourself," Frankel had said at the meeting. Mills had wielded an "honest and fighting intellect" in the service of ideals for which he had proved his willingness to pay the highest price. "He was charitable with others, never charitable with himself."

The closer Frankel came toward power the lower went his opinion. At the time of the Commemorative Meeting he was employed at the Brookings Institution on a study of the Department of State's Bureau of Educational and 
Cultural Affairs, work that caused him to be appointed Assistant Secretary of State for Educational and Cultural Affairs in the administration of Lyndon Johnson. Interviewed by Newsweek in April 1964, Frankel spoke viciously of his former friend. Mills, he said, was "very much a second-rate sociologist" whose judgments were quick, gross, and methodologically unsound. "He drove ahead hard all the time, and through and over people, unless they were as tough and big as he- then he'd stop and take notice." He ruined his wives, he knew little about culture ("he had no taste") and even less about the human beings whose company he both needed and feared. At the end of his life ("a clear case of suicide") the violence dwelling in his personal character escaped, turned against his country, and then against himself. Frankel said Mills reminded him "a great deal" of Lee Harvey Oswald. ${ }^{61}$

Nor was this the worst of it. Edward Shils represented liberal loathing at its meanest. Unlike Frankel, who resigned from the State Department in 1967 to protest the Vietnam War, and unlike Irving Howe, who stopped equivocating in 1968 and started calling for an unconditional withdrawal of troops, Shils supported the war all the way through. His third essay on Mills, appearing in The Spectator in London, had a lurid title, "The Great Obsession," though its contents merely restated its author's conviction to the effect that Mills's biography rested on a fraud all the more astonishing for its widespread acceptance. Shils allowed that the portrait of American civilization painted in his trilogy struck closer to reality than anything available in the writings of the postwar literati, though this was not much of an allowance. For the trilogy upheld another kind of confusion, according to Shils. Mills had jammed together images by German idealism, American populism, and Western Marxism. Echoes of Veblen, Weber, Trotsky, and Kafka were nothing more instances in a chaos that erupted against the background of a formless rage. Only his vainglory obscured his incoherence. "He liked to think of himself as an outlaw, a Prometheus, a last-ditch fighter, a lonely bull, an embattled hero who would never yield to coercion or seduction. He liked to put on the airs of a man who was attacked on every side by overwhelming odds but who would never give up." Shils saw through it all. "Of course, the self-portrayal was completely a selfdeception, he was not a hero in any way." ${ }^{2}$

There was no gainsaying his influence. Shils thought he had aroused a global public greater than any sociologist in American history. But it was the complacency of liberal society, rather than any special genius Mills may have possessed, that allowed him "to play his rat-catcher's pipe" on a world scale. Like the Pied-Piper himself, who struck while Hamelin's citizens were in church, he had preyed upon the ugly features of society, baring his resentments by seducing its children. ${ }^{63}$ "Now he is dead," Shils gloated, "and his rhetoric is a field of broken stones, his analyses empty, his strenuous pathos limp." ${ }^{\prime 4}$

As these comments suggest, memories of Mills reactivated the rivalry of leftists and liberals which had lain dormant since 1948, when New Deal political society 
reconstituted around Cold War anti-communism. Liberalism in the 1950s, having abandoned the left to the red hunters and having discredited the radical right, had emerged victorious from the bloodletting. No longer confronting any real challengers on the plane of ideas and ideals, defenders of the liberal creed worried about growing soft. The election of Kennedy removed this worry even as it appeared to validate the strategic wisdom of Arthur Schlesinger Jr.'s The Vital Center, a key tract in the ideological realignment of 1948. But Mills had survived the bloodletting as well. And now his legacy of non-communist radicalism presented an unexpectedly potent danger to liberals who found themselves staring at a resurgent Left at the very moment they had regained the White House. Those who assumed that liberal society had the manifest purchase on the world's future naturally interpreted this development as sabotage, with Mills swinging the hammer from the grave.

Tom Hayden, the new president of SDS, drove with a colleague to the White House, right after the Port Huron conference. There he met with Schlesinger, who promised that he would bring the Port Huron manifesto to the President's attention. Nowhere in A Thousand Days (1965), his 1000-page history of the administration, did he mention either the meeting or the manifesto. Hayden might have guessed. In 1948, Schlesinger had hailed The New Men of Power as "a brilliant, original, and provocative work, genuinely democratic and boldly radical in character." ${ }^{55}$ A decade later, however, he had sharply rejected The Causes of World War Three in the New York Post, and then, writing in the New York Times Book Review, had congratulated Daniel Bell for "destroying" The Power Elite. ${ }^{66}$ Schlesinger professed to be puzzled that the book had achieved its wide currency. "President Eisenhower's phrase about the 'military-industrial complex' always seemed to me anodd capitulation on the former President's part to C Wright Mills's theory of the power elite," he wrote.

There would be no kind of capitulation on Arthur Schlesinger's part. In January 1962, in a speech before the California Federation of Young Democrats, he drew a disgraceful equivalence between the New Left and New Right. "When I hear talk of 'the power elite,' I know that I am in the presence of a mirror image of the John Birch Society. The notion that a conspiracy of bankers and generals controls our destiny is as nutty as the notion that it is controlled by Walter Reuther and the officials of the ADA." 68

Schlesinger sent his speech to William F. Buckley, who reported its contents in the Los Angeles Times. Buckley had been chagrined to read of Schlesinger's frequent attacks on the New Right. At a debate in 1961, Buckley had dared him to disassociate the New Frontier from the New Left and promised to publicize any such criticisms. Schlesinger, accordingly, reached two audiences with the same speech. He warned young Democrats against Mills and reassured established Republicans. Since Buckley found it easy to agree that the power elite was "a lunatic notion," it is only fair to complete the logic of equivalence. To believe that Mills had something in common with the John Birch Society, it is necessary also 
to believe that Schlesinger and Buckley shared a corresponding trait. Schlesinger, indeed, overcame his early admiration for Mills just as Buckley overcame his early admiration for the Birchers. Then, both men proved their willingness to wield the commissar's scalpel, cutting out ideological undesirables like abscesses on the ripening flesh of The Party.

The portrait of Mills by leading liberals discouraged hope that public argument between the New Left and the New Frontiersmen could return much in the way of educative value. Frankel, Howe, Shils, and Schlesinger afforded no possibility of learning anything useful about him, advanced no good reason to explain his following. Then again, perhaps this was the wrong kind of knowledge to look for. By signifying a position in relation to Mills, they signified their position in relation to one another. Mills himself understood this need to take and hold a position against political enemies. (If anything, doing so was more important, and often more difficult, for an insurgency than for established traditions.) The effect of mocking Schlesinger and Bell by name in the "Letter to the New Left" was to force divisions into the open, to create a position from which the new radicals could define themselves. Even as he acknowledged that he shared many liberal values he attacked its social and political theorists pitilessly from the beginning of his career until the end, by which time he had turned the very phrase, liberal intel lectual, into an epithet symbolizing ineptitude, flim-flam, and complacency. The more Kennedy's liberalism showed itself anything but complacent, the more ferociously he hit. After the Bay of Pigs, he accused Schlesinger of defending "a New Frontier of thieves and murderers. What else can one conclude?" began calling "a shallow and cowardly sheet whose total political wisdom or formula seems to be: communism of all sorts is homogenous and eternal evil plus America is a mass society and this isn't so good either."70

And yet Mills and Schlesinger had more in common with one another than either man had with Dissent. Mills's books shared with Schlesinger's The Age of Jackson and The Age of Roosevelt a concern not only to delineate the relations of morality and politics at the highest levels in America, but to influence them personally. Neither man hesitated when the chance arrived. Listen, Yankee exulted in the "revolutionary euphoria" permeating the "new men" of Cuba. A Thousand Days exulted in "The Hour of Euphoria" permeating Kennedy's Washington, "the excitement which comes from an injection of new men and new ideas, the release of energy which occurs when men with ideas have a chance to put them into practice." ${ }^{71}$ Both Mills and Schlesinger were engaged in an attempt to influence power in a humane direction at the moment when it was most open to their influence, and both men showed an admirable consistency in this desire over the course of their careers. Only one of them, however, lost his balance in a frenzy of intoxicated apologetics.

Imagine Mills had taken a leave of absence from Columbia and put aside his multivolume scholarly project in order to work for the Cuban govern- 
ment, reporting directly to Castro. Imagine that, in this capacity, he had composed a public justification for an illegal, unprovoked paramilitary operation to be waged by Cuba for ideological reasons against a much weaker nation, and imagine further that this justification had been accepted without challenge in the press as a balanced appraisal of the exigencies of the moment. Imagine that he had registered his doubts about the operation privately, then had lied to the Cuban equivalent of the New York Times about its significance, after which, at the behest of Castro, he had suppressed a critical report in the Cuban equivalent of the New Republic. Now imagine that after it was all over he published a history in which he glorified Castro's charisma, assumed the benevolence of his domestic policies, and connected the unilateral exercise of his power abroad to the salvation of the world. Had Mills committed any one of these acts, America's liberals would have accused him of betraying his obligation to tell the truth. Schlesinger won the Pulitzer Prize.

So it was that Mills's disciples in SDS, having searched contemporary liberalism with his critical eyes, and having concluding that it offered no theory of society or politics adequate to the age beyond ideology, mounted their challenge. The mildest form of this challenge held out hope that it could revitalize longstanding liberal values. Economic prosperity had instilled "quiescence in liberal hearts," according to the Port Huron Statement. ${ }^{72}$ The greater challenge was changing a society currently inhospitable to those values. In America and the New Era, a sequel to the Port Huron Statement written in 1963, the liberal intellectuals manning the administration were presented as enlightened managers of the "Establishment." Even when these managers could be made to acknowledge flaws and absences in "the going system" they deprived them of dialectical significance by a strategy of "aggressive tokenism."73 The student movement stood for imperiled democratic values. The weapons of catastrophic violence and their place in Cold War affairs had "created a world in which virtually every human value was distorted, all moral standards seemed weirdly irrelevant, all hopes and aspirations appeared utopian." 74 Anger, not mere disappointment, direct action, civil disobedience, and mass protest, not mere electioneering, encompassed the proper range of response.

The New Frontier gave them much to be angry about. To judge the administration's foreign policy in light of the Mills's writings was to be struck again by the tragedy of his early exit. It was not only that the administration and its surrogates tried to assassinate Castro, nor that it matched its contempt for international law with a contempt for an independent and free press at home. The greater problem was structural, more difficult to see but consequential in all the ways that Mills had opposed. The Alliance for Progress, the centrepiece of Kennedy's Latin American policy, showed the critical distance between liberals and radicals in the 1960 s. 
Meanwhile, in a part of the world far away from Cuba, another European empire was collapsing, and in the felt need for the United States to fill the vacuum the power elite made another people pay for its mistakes. Once again, liberal intellectuals mistook revolutionary nationalism for a conspiracy of communists. Once again, Congress abandoned its legal obligations to the selfaggrandizement of the executive branch. Once again, the press declined to discuss open secrets. The war in Southeast Asia was prosecuted by four administrations from both parties, touched every organ of government, and proved to the horror of Mills's admirers that Washington's men of power were willing to wreak atrocities upon the most helpless enemies of state. In the end, the liberal consensus of the long postwar era wrecked itself on the very combination of benighted idealism and cynicism he had criticized in his writings.

Two weeks before President Kennedy was assassinated, he told a French journalist that the United States probably did bear a measure of responsibility for the Batista years in Cuba. But what could he do? He had purchased his power at the price of Cold War. The logic of its demands had held him hostage. "I am the President of the United States," Kennedy observed, "and not a sociologist." 75

Like Thorstein Veblen, who died in 1929, Mills died at the dawn of a decade whose most flamboyant features his vision was the first to illuminate. Yet neither his epigones nor his enemies generated anything like Joseph Dorfman's Thorstein Veblen and His America (1934), no biography in the absence of which informed disagreement miscarries. Mills admired Dorfman's book in college. Later, he added Ernest Jones (on Freud) and Isaac Deutscher (on Trotsky) to his short list of model biographers. But no equivalent has stepped forward to relate his life to the political and social issues he had advanced. Around Mills's legacy instead appeared a false logic of venerating and debunking, one that took root almost immediately after his death.

"Shortly after his death," Dan Wakefield complained in 1971 memoir, "Mills and his work were being claimed by various individuals and groups to support their own stances, whether sociological or political, and if in some ways he left himself open to this with his overenthusiasms and generosities, I don't think he deserves it. Of all the men I have known, Mills was the most individual, the most obstinately unorganizable, the most jealous of his right and need to 'go it alone' and to fire at all sides when he felt so moved." W6 Wakefield's own career showed that admiration need not entail imitation. His books, Island in the City (1959), Revolt in the South (1960), and Between the Lines (1966) resisted the role of political activist yet took their place alongside the best liberal journalism of these years.

Mills himself had held left-wing movements to be "as snobbish in their assignment of prestige as any national establishment." 77 Given the New Left's 
emotional urge and political need to monumentalize, given the number and variety of mythological personalities to grow in his shadow, instances of outright suppression were few.

Saul Landau had been reading him since White Collar. As a member of the Communist Party's Labor Youth League at the University of Wisconsin, and as an early editor of the magazine Studies on the Left, Landau approached the "Letter to the New Left" with suspicion of its departure from Marxist dogma. But like other young leftists bewildered by the events of 1956, he laid himself open to new leadership. Landau met Mills in Havana. The next year, he accompanied him to Europe and Russia as his personal secretary. The months of intimate contact Landau enjoyed over the long summer of 1961 disclosed a quality of observation rare among Mills's admirers. Landau co-wrote a satire of John Kennedy with him and saw it published in the London Tribune on the occasion of the president's first 100 days in office.

But "The House That Jack Must Build" was Mills close to his worst, his natural optimism now disfigured by unbridled sarcasm. ${ }^{78}$ In a memoir of their time together, Landau depicted a man defeated to the brink of despair, a victim of a confrontation between the violent antagonisms in his character and violent world he had made his burden. Haunted by thoughts of vengeance for his enemies, petty, sometimes cruel with his friends, Mills's daily conversation emanated statements no disciple could abide. He told Landau (whom he knew was Jewish) of a German friend, a former SS officer, with whom he enjoyed motorcycling. He spoke of the British as "limeys" and the French as "frogs." He ate himself sick, and every day, in the early afternoon, he swallowed sleeping pills and cognac in quantities large enough to stun two men. When he was really soused he talked of suicide, of Hemingway's suicide, and of his own. Before the trip to Europe, Landau regarded Mills as a prophet. Now he remembered him as a tragic figure worthy of respect, not of veneration. ${ }^{79}$

Landau mailed a draft of the memoir to Mills's widow, Yaroslava, on 6 June 1962, accompanied by a note that indicated he might hope to write a biography. Several days later, Ralph Miliband came to West Nyack for a visit. Miliband read the memoir and wrote Landau demanding that he suppress its unflattering features. Miliband confirmed that Mills had spoken with him in the same manner, about many of the same subjects. He agreed, moreover, that the debility of his final months had generated a caricature of his traits. But Miliband held, nonetheless, that enemies were sure to make use of the memoir. Landau capitulated. He deleted mention of the SS officer; reinterpreted Mills's aggression as Socratic dialogue; cleaned up the vulgarities in his speech; and softened anecdotes about his drinking to the point that few readers could have inferred the onset of alcoholism. Landau, in his reply to Miliband, berated himself in a manner befitting the Party cadre he once planned to become. Sanitized versions of the memoir appeared in Root and Branch and Ramparts. Landau read a version over KPFA radio in Berkeley 
on 7 September $1962 .^{80}$ The biography never appeared.

The intimate knowledge Miliband possessed he laid away in a monitory tone that did not educate younger radicals in the full range of honest responses to Mills. Too close for critical detachment, he mourned "bitterly and personally" in an obituary in the New Left Review, one of three short pieces he wrote on his American comrade. ${ }^{81}$ Mills, in these pieces, appears as a political leader whose anarchism never made a fetish out of opposition and as a critic of power who never evaded its responsibilities. This poise, so rare among intellectuals, governed his personal relations as well. "He was a singularly modest, unpretentious man," Miliband said. "He never made the vulgar mistake of taking seriously only those who shared his view of the world." About his weaknesses and failings Mills had been acutely sensitive. If he had exaggerated his isolation, that was because the United States lacked the kind of socialist parties and organizations to which he warmed in Europe. If he had placed too much hope in the intellectuals, that was because he had been quick to see that the older agents of change had collapsed. "In a trapped and inhumane world, he taught what it means to be a free and humane intellect."

Miliband's portrait reached its limits in its refusal to admit the legitimacy of dissenting views. In a letter to Dissent, written in reply to a memoir of Mills by Harvey Swados, Miliband rebutted its "inaccurate, offensive, and plain nasty" portrait without explaining its motives. Miliband simply accused Swados of jealousy. "I have never met Mr. Swados but I have known him as an intelligent and sensitive writer. Why then does his essay breathe spite and venom? There is of course the fact that Mills had a very disturbing effect on many people-his vitality, his intensity, the extraordinary diversity of his skills all seemed to pose a challenge to friends and associates, and so did the recognition he gained in his last years." ${ }^{{ }^{82}}$ In 1965, Miliband and his wife Marion named their newborn son David Wright Miliband in honor of their martyred friend. Miliband dedicated to Mills his breakthrough book, The State in Capitalist Society (1969). "I got to feel closer to Mills than I have ever felt to any man, or shall ever feel again, I should think," he told E.P. Thompson. ${ }^{83}$

The absence of biography, or many-sided assessment, was eloquent of the larger failure of the New Left in the 1960s to generate the distinct theoretical perspective for which Mills had called in the "Letter to the New Left." As SDS expanded and intensified over the course of the decade, it exposed the limits of Mills's influence. It was not only that he left unfinished The Cultural Apparatus, which might have unified the SDS intellectuals, the bohemian counterculture, and the civil rights intellectuals. Key issues he left unresolved, though not unacknowledged. In notes and manuscripts for a book project he titled The New Left he returned again and again to ruminate on two issues, in particular, he believed that the new radicals would have to confront.

Violence was the first. Mills defended the owning of guns as "a fundamental human right" and advocated citizen's militias. "I am a very old fashioned 
conservative American—one man, one vote, one rifle, and one woman at a time." ${ }^{84}$ In a letter he was more explicit and more discriminating, yet faltering all the same. "The truth is, I think, I've always believed in calculated, cold-blooded personal violence, one man at a time. Up against another man, or maybe even two, it's somewhat up to you who gets killed. Perhaps that is why I am so much against war, as it is nowadays absurdly conducted: you do not even know the people you are killing off." ${ }^{85}$ He began writing The New Left in January 1960; he added notes and outlines into 1961. Alongside statements of belief in violence he laid down equally fervid affirmations of the moral superiority of civil disobedience, such as this one: "Non-violent resistance is not merely a set of values and not merely a set of techniques. It is a new method of making history, perhaps the most radically innovative one in world history." He was honest to confess that he had not worked out a position that satisfied him.

Communism was the second issue. To be anti-communist or non-communist? For intellectuals even to begin to think about the issue of communism was to become entangled in the paradoxical history of Marxism. Mills had unwound the tradition into threads he named "plain Marxism," "sophisticated Marxism," and "vulgar Marxism." He had identified himself with the first and complained that the last two had tangled radicalism in modern America so badly that nobody could find a single first-rate thinker, nor any substantial new interpretations. Any movement that aspired to internationalism would have to do better. Everywhere communism had seized power it articulated its authority in the language of Marxism. Everywhere else communism was merely socialism, and socialism without the single most powerful theoretical armature devised for it was "merely a holier than thou moral doctrine." 86 It was this moral core in American Marxism that had attracted literary figures in the 1930s. Since then, however, native Marxists had become "an obstacle" to new left thinking. "They must mend their intellectual manners and increase the clarity of their work by adopting a different vocabulary," Mills contended in The New Left. "At present theirs has two deficiencies: it is full of stereotyped jargon and it is full of repelling invective of abuse." ${ }^{87}$

As the 1960s wore on, these ambiguities concerning revolutionary violence and Marxist communism tangled Mills's legacy into a series of paradoxes at home as well as abroad.

In Czechoslovakia, for example, the Communist Party had ruled since instigating a coup in 1948; and one sign that the "thaw" was finally reaching here was that Mills showed up on the curriculum at Charles University, Czechoslovakia's oldest, largest, most distinguished, and most closely monitored institution of higher education. Another sign was growth in sociology. In 1964, a department opened at Charles and a Slovak Sociological Society met for the first time. As in the other satellite nations of Eastern Europe, the discipline had been shrouded in Soviet Marxist philosophy. Now, in 1966, the new Czech and Slovak sociologists attended their first World Congress of the International Sociological Association, 
the same year the Orbis Publishing House, in Prague, issued a translation of The Power Elite. ${ }^{88}$

Communist translators often got more than they expected from the book. Because it attacked bourgeois illusions from within American society, it served the immediate interests of the Party. But because it advanced a model of power that was at odds with Marxist theory, because it rejected the concept of the "ruling class" in favour of "elites" and "masses," it offered a vocabulary that served the interests of the growing number of dissidents clamouring for alternatives to one-party rule. In the introduction to the Czech translation, Miroslav Jodl noted "the theoretical stagnation here" and insisted that "it is necessary to point out that Mills was not a Marxist." The value of The Power Elite rested on "extraordinary importance of the category of power, which cannot be simply reduced to the term "class supremacy."' In creating a sociological model by which to understand the concentration of power in societies both capitalist and communist "Mills made the first steps to a world sociology," said Jodl, a member of the new sociology section at the Czechoslovakian Academy of Science. "By translating Mills's work we pay tribute to a noble humanist, who in the range of his capacities and limitations roused the conscience of humanity." 89

In January 1968, Antonin Novotny, First Secretary of the Communist Party, resigned and was replaced by Alexander Dubcek. Reformers led by artists, novelists, playrights, and philosophers hoped, as the Poles and the Hungarians had hoped in 1956, that the change in Party leadership would bring about a more humane form of socialism, that the Party was capable of reforming itself. Stalinism had been especially terrible in Czechoslovakia, so the sweeping reforms that Dubcek and his allies implemented in the spring and summer decisively altered the political temper of the country, stimulating hunger for more. "Truth provokes power," said Ivan Sviták on July 18, in the first issue of Literarni listy, a periodical founded by the radicalized Writers Union to express the discontent, "not because someone wants to provoke the power elite, but because a mere mental reproduction of the existing conditions is prosecuted by the power elite as a personal offense to the powerful." " On July 30, writing in Student, Sviták advised the protestors to remember that "the power elite has under all circumstances one overriding interest-to maintain itself in power." A philosophy instructor at Charles University and a colleague of Miroslav Jodl at the Institute of Philosophy of the Academy of Science before being expelled in 1964, Ivan Sviták was the most radically democratic of the dissidents, the man most willing to depart from the canting dogmas of Soviet Marxism. In calling for freedom of speech, competitive parties, and workers' control over factories, Sviták did as much as any single figure in these extraordinary few months to rally public opinion. Czechoslovakia, he insisted, must transform itself from "the bureaucratic management of society and culture by the 'cutthroats of the official line' (an expression used by Wright Mills) to the realization of basic human and civil rights." 
Heads Against the Wall, a collection of Sviták's manifestos, speeches, and essays, went to press in August 1968, just before the Soviets brought the protests to heel with their largest military force since World War II. Jodl, Mills's translator, lost his job at the Czechoslovak Academy of Science and his membership in the Party and went to work as a typesetter. Sviták lost his citizenship and was indicted for treason. Out of the country during the invasion, he was tried, convicted, and sentenced in absentia to eight years in prison. The invasion finished off a decade of hope that a renaissance of socialist political culture could root in the aftermath of 1956.

In Havana, Mills's ambiguities concerning revolutionary violence and Marxism returned virtually the opposite consequence. Rather than encouraging creative dissent against tyranny, his writings ended in dogmatism and complacency. In January 1968, 500 delegates met for an International Cultural Congress in Havana on the theme of "The Intellectual and the Struggle for the Liberation of the People of the Third World." Todd Gitlin, attending the congress for SDS, filed his impressions in two essays. Gitlin said he found everywhere in Cuba "willed commitments" forged in sympathy with free art and poetry. The entire society, he said, was moving toward the kind of "moneyless future" that American liberals could not comprehend. "Cuba stands as a model of what it is this system wants to discredit and destroy," Gitlin wrote, without reporting any sign of political conflict or internal division on the island. Three weeks after the delegates went home, Cuban officials arrested 41 men for attempting to organize "microfactions." Although the men were not permitted to speak in court, and although there was no law against "microfactions," they were convicted, imprisoned, and sentenced to hard labour. On 13 March, while Gitlin argued that "Cuba is, of course, a lesson that the communal spirit is not always dependent on an active war-footing," Fidel Castro announced the "Great Revolutionary Offensive" in order to combat a widely acknowledged decline in the communal spirit. The Offensive shut down thousands of bars, cabarets, and small shops, ended the trade in black market goods, reorganized agricultural production on the model of the army, and in general geared the country into emergency mode. On 2 August, six months after Gitlin argued that Cuba's foreign policy stood for the "liberation of humanity," Castro endorsed the Soviet invasion of Czechoslovakia. ${ }^{93}$

Gitlin worried that he had not looked hard enough for conflict within Cuba's new society, and when Castro backed the Soviet invasion, he felt disgusted, and said so. Indeed, as another inheritor of Mills's legacy showed even more clearly, Listen Yankee did contain the seeds of self-correction. K.S. Karol was a schoolmate of Leszek Kolakowski in Poland, a conscript in the Red Army, a prisoner of Stalin, and, after the war, a journalist. Mills's writings on the Cuban Revolution contained the seeds of self-correction, as K.S. Karol proved. A schoolmate of Leszek Kolakowski in Poland, a conscript in the Red Army, a prisoner of Stalin, 
Karol drifted into journalism after the war. He reported on European politics for New Statesmen, making ample use of the five languages he spoke, and covered the Polish October of 1956 for a French newspaper, L'Express. Karol and Mills had little in common by dint of temperament or background. Nor were they brought together by foundation grants, university exchanges, or diplomatic programs. They met in the lobby of the Hotel Theresa in September 1960, during Castro's visit to Harlem, and struck up a friendship. Mills used his influence in Havana to gain Karol a personal interview with Che Guevara. Karol used his influence in Paris to arrange lunch with Sartre and de Beauvoir. In the autumn 1961, Mills and Karol went on picnics together in the French countryside.

Karol recalls the pensive mood of these visits. "It made one sad to see this Texan-and I have never met anyone more typical of the free and independent American pioneer-up against a solid wall of hostility and vilification." ${ }^{94}$ Solidarity was a strong tonic. "Mills was very well received by my friends," Karol says, echoing the opinion in Copenhagen, Mexico City, London, and Warsaw. "He was a very friendly and likable man." 95

Karol had returned to Cuba three times in the decade, enjoying Castro's confidence, before publishing one of the best books ever written on the revolution: Guerrillas in Power. Karol cast it as a successor to Listen Yankee. "Eight years later, we can see how right his predictions were, and how shrewdly he discerned some of the obstacles on the Cuban road to socialism." 96 Mixing personal observation with political and historical analysis, Karol called the events and decisions during 1961, the period that had plunged Mills into the despair from which he never recovered, a period of "mini-Stalinism." 97 Since then, he said, the problems besetting the revolution had not been resolved by building voluntary organizations, nor by holding elections to generate political knowledge, but always by extenuating the executive powers of the state. Cuba remained freer than most socialist countries, but the quality of its journalism, literature, and scholarship was poor; information failed to circulate efficiently; and the intellectuals had responded to virtual cultural dictatorship by withdrawing from political affairs. The double-standards in private and public morality as well as the persistence of black markets and economic deprivation reminded him of life under Stalin in the 1930s. Karol concluded that primitive socialist accumulation almost inevitably brought authoritarian leadership and coercive public measures. When Guerrillas in Power was published, Castro, as if to prove the point, accused Karol of working for the CIA. Would they same fate have visited Mills?

Another kind of ambiguity showed itself in the student movement. The "Letter to the New Left" implored radicals to consider that "the cultural apparatus, the intellectuals" may be best positioned to subvert the social order and to initiate a new beginning. Mills's success in spreading the message even he could not have anticipated. In September 1968, the CIA concluded a classified report, "Restless 
Youth," which identified Herbert Marcuse, Mills, and Frantz Fanon as the three leaders of the international left. Between Marcuse's abstract Marxism and Fanon's revolutionary violence, there was Mills's ghost, chasing both action and ideas without acknowledging the need to choose. He challenged the youngest of the intellectuals to create new values out of the dialectic of thought and action, but he could not tell them how to tell the vital difference between thinking too long, and acting too soon.

SDS opened a chapter at Columbia University in 1965. Late though SDS was in coming to campus (51 chapters had opened elsewhere already) it was not long in making its presence felt. Over the next three years, its members staged a series of protests against campus recruiters, spoiling presentations by Dow Chemical Company and the CIA, and, once, hitting a Selective Service officer in the face with a lemon meringue pie. Columbia President Grayson Kirk responded to the militancy on campus by issuing a ban on indoor demonstrations. A group of students quickly violated the ban. Kirk suspended them. ${ }^{98}$

Here, as elsewhere, not only the decisions of the authorities, but the authority to make decisions drew the challenge of the students. University officials punished them for defying the rituals of dissent. The punishments spurred bolder acts of defiance. On 23 April 1968, SDS rallied 900 students on the steps of Low Library to protest the recent suspensions. About one-third of the rally peeled away and went to the site of a gymnasium the university was building over their objections. Arriving at the construction site, they tore down a fence. Then a group of students entered Hamilton Hall, let it be known they intended not to leave, and held the Dean of Columbia College hostage.

The events of the next few days plunged the university into the worst crisis in its history. Militants used a bench to batter their way inside Low Library, where they entered President Kirk's suite of offices and discovered a cache of secret files. Students from the School of Architecture refused to leave Avery Hall. Another group, comprised of 50 graduate students in history and social science, barricaded the front doors of Fayerweather Hall, where Robert Merton and Paul Lazarsfeld had their offices. Stokely Carmichael came to Hamilton Hall, now renamed Malcolm X Liberation College, and conferred with the black students inside. Elsewhere, red flags shot upward from the roofs. Five buildings had fallen in three days.

On 26 April 1968, Columbia closed.

Here, as in Prague, university officials met the nonviolent disruption of social order with an overwhelming display of physical force. At the request of President Kirk, 1000 policemen stormed the campus, arresting nearly ten percent of the students in the College. A general strike virtually halted the business of the university. Militants seized a nearby apartment building and were quickly ousted by police. On 23 May, several hundred students occupied Hamilton Hall in response to the administration's decision to suspend four SDS leaders. When the 
police arrived this time the students lighted fires and threw bricks. Seventy people were injured.

President Kirk and Provost David Truman soon resigned, having lost the confidence of the faculty as well as the students. For the first time in the university's long history, a member of the faculty was asked to deliver the annual commencement address. Richard Hofstadter tried to find common ground in his remarks, given on 4 June in the Cathedral of St. John the Divine. "Here at Columbia, we have suffered a disaster whose precise dimensions it is impossible to state, because the story is not yet finished, and the measure of our loss still depends upon what we do." ${ }^{\prime 9}$ As soon as Hofstadter began speaking 300 students and faculty stood up, turned their backs, and walked out.

What would Mills have thought? He would have recognized the personalities and politics involved. Michael Klare, a former student, co-wrote a pamphlet, Who Rules Columbia?, that looked a lot like The Insiders, the pamphlet Mills had inspired in an earlier generation of student radicals at Oxford University. Who Rules Columbia? used the incriminating documents pilfered from President Kirk's office to argue that the Board of Trustees ran the university like a factory, that it palmed off its financial resources to real estate interests in Manhattan, that it produced skilled technicians for the permanent war economy, that it struck secret deals with military intelligence agencies while neglecting the needs of the university's poor neighbours. Fast was Columbia changing from a liberal college into an auxiliary of "the U.S. power elite." 100 The evening before the bust, Klare sneaked out of Fayerweather Hall and spoke at the " $\mathrm{C}$. Wright Mills Memorial Teach-In" in Ferris Booth Hall, a student centre and dormitory that SDS was using at its headquarters. ${ }^{101}$

Tom Hayden rushed from his office in Newark to Morningside Heights as soon as he heard news of the occupation. Hayden had showed in recent years a growing interest in guerrilla warfare and revolutionary politics. At Christmas 1965, he had traveled to Prague, Moscow, Peking, and Hanoi, "contacting the enemy." He had co-published The Other Side (1966), a volume of interviews and reflections made in the image of Soviet Journal and laced with long quotations from the man himself. ${ }^{102}$ For four days at Columbia he presided over a spontaneous commune in Mathematics Hall, instructing teams of militants how to slick the steps with soap in preparation for the police. Writing in Ramparts after the bust, he dared students across America to create "two, three, many Columbias." The phrase referred to Che Guevara, who had implored revolutionaries across Latin America to create "two, three, many Vietnams" four months before he was murdered in Bolivia. Hayden looked forward to heightened confrontations with faculty and envisioned radical students as a vanguard. "They are, in Fidel Castro's words, 'guerrillas in the field of culture."”103

Mills's old adversaries responded to the occupation in terms first forged in their confrontations with him. The administration's failures Bell attributed to cowardice and ineptitude, whereas the motives of the students he said had been 
perverse. Possessed by an "anarcho-syndicalist mood of rebellion," they had proved incapable of the kind of responsible political action that would have remediated their discontent. Bell rejected the use of police power by the administration (he had led an Ad Hoc Faculty Group in its failed effort to mediate the dispute) and at the same time likened the atmosphere on the campus to a religious frenzy. Lionel Trilling told Partisan Review: "The nearest thing to a feeling that I can now recall or experience is my puzzled preoccupation with what the students are and want." ${ }^{104}$ Bell conceded the same note of confusion, in spite of his expertise in the history of radicalism, and in spite of his intimate knowledge of the characters and events. "As I have studied this history, and reflected on my own participation in it, I find the 'outbreak,' 'uprising,' 'revolution'-none of these words is adequate-extremely puzzling." 105 Eight years earlier, responding to the "Letter to the New Left," Bell had pronounced himself "bewildered" then too.

Mills would have recognized, moreover, the double standard in these responses. All along, liberal and socialist critics of the New Left demanded an unequivocal, unqualified statement against police power in one-party communist societies. Yet no such critic mustered any such statement against Columbia's administration. Irving Howe, borrowing the logic of moral equivalence he deplored in the student radicals, argued that they had invited police violence by their provocative conduct. Charles Frankel's Education and the Barricades (1968) took a high-minded tone, but insisted, like Howe, that the students should have expected violence. That none of the students had carried a gun or a bomb in the occupation, that they had engaged in a symbolic disruption only, that they had been easily and decisively routed, that New York's Civilian Complaint Review Board recorded nearly 400 complaints of police brutality and 150 injuries in the aftermath, none of these considerations drained the collective response by Bell, Trilling, Frankel, and Howe of its reactionary sentiment. Hofstadter, in his commencement address, spoke eloquently of the university as "a citadel of intellectual individualism," as an independent institution dedicated to the free play of reason in defiance of political pressures. But Hofstadter knew better than anybody that colleges and universities had never been independent of political pressures, that postwar higher education was deeply implicated in the Cold War. Even as he spoke in defence of the ideal, dozens of policemen, some uniformed, others distributed secretly in the audience, crept about the Cathedral.

Much like his fellow liberal professors, Hofstadter suffered bouts of confusion and disorientation. "If I get around to writing a general history of the recent past," he told Newsweek in the summer 1970, "I'm going to call the chapter on the "60s "The Age of Rubbish."' 106

Hofstadter had joined with Daniel Bell, Charles Frankel, Talcott Parsons, Phillip Rieff, David Riesman, Arthur Schlesinger Jr., and David Truman in rejecting The Power Elite, The Causes of World War Three, and Listen, Yankee. Yet not of Mills's critics had anything better to propose, no new ideas to take the full measure of the damage done to American institutions by the Cold War. 
In explaining the "crisis of confidence" that followed the crises of Vietnam and Watergate, Schlesinger's The Imperial Presidency (1973) interpreted the extraordinary arrogance of power in these years as the culmination of long-term changes in American society. Yet he stopped short of recommending reforms of a corresponding scope and significance. He held the line against proposals to transform the presidency into a more democratic institution, urging instead a kind of patrimonial solicitude for the Constitution which would reign in the office while at the same time preserving the singularity of its executive mode of action. But Schlesinger's analysis was spoiled by the same easy conflation of law and morality in the public declarations of his Soviet counterparts. (In urging future presidents to "rehabilitate" the office, he said, revealingly, "I use the word in almost the Soviet sense." ${ }^{107}$ ) Declining to call into question the party-consensus on the Cold War's ends, The Imperial Presidency skirted the greater question of whether the ends were inherently immoral, however well their institutional framework satisfied the Constitutional theory of power.

Meanwhile, the New Left uncannily reenacted Mills's biography, completed the same short course from utopian speculation and experimentation to confrontation, escalation, crisis, and disappointment.

Hayden left New York for Chicago. There he conferred with Bob Ross and Richard Flacks, in whose apartment he stayed. "Columbia opened a new tactical stage in the resistance movement which began last fall," he wrote. "What is certain is that we are moving toward power-the power to stop the machine if it cannot be made to serve humane ends," he wrote, in the same vein of misbegotten prophesy. ${ }^{108}$ In Chicago, protesting the Democratic National Convention, Hayden found troops and tanks guarding the streets. He suspected (correctly) that FBI agents were following him. All this made him more eager for an armed confrontation. His speeches no longer glistened with the ideal content of democracy, as they had at Port Huron, but hinted at the redemptive value of violence. Arrested and assaulted by police agents, trailed by spies and threatened with murder, he began experimenting with guns and wearing disguises. He went underground, ending the 1960s as Mills had ended the 1950s: the most famous, the most isolated, and probably the most exhausted radical intellectual in America. Murray Kempton pronounced Hayden a candidate without a party, just as Hans Gerth had pronounced Mills an officer without an army.

Flacks and Ross fared little better. In August 1968 a crew of graduate students from Columbia joined with veteran radicals to form the Sociology Liberation Movement (SLM), an effort to drive the attack on the universities into the professions. They challenged the profession's semi-closed system of hiring and promotion. Flacks organized for the SLM, as did Ross, who was now national director of the New University Conference, an instrument designed to forge from various leftist initiatives a permanent faculty and student organization. 
Like Mills, however, they soon found themselves unexpectedly vulnerable to the disappearing distinction between their political, professional, and personal lives. Ross was suspended from the University of Chicago after chairing a mass meeting where the students voted to occupy the administration building. For years afterward Ross suffered from an acute anxiety, symbolized by a debilitating skin disease that made its appearance soon after he left campus. His injuries were nothing next to Flacks's. On 5 May 1969, a man appeared at the door of Flacks's office and lunged toward him. The stranger inflicted multiple head fractures and nearly severed his right hand before leaving him for dead. Just before the attack, the Chicago Tribune had named Flacks as a dangerous antiwar activist, and the FBI had sent a secret, anonymous letter to the university's Board of Trustees, attempting to have him fired.

The Sociology Liberation Movement (SLM) suffered from wounds intrinsic to its project. At the 1969 convention of the American Sociological Association, in San Francisco, the SLM staged a counter-convention. A vanguard crossed the street, took over the presidential address platform and tried to raise a memorial to Ho Chi Minh. "Fat-Cat Sociology," a SLM working paper, accused the assembled sociologists of serving as technicians of the Vietnam War, as guardians of "the occupied populace," and as leaders in a "criminal" system of education. ${ }^{109}$ The Insurgent Sociologist, a newsletter, explained that SLM wished "to destroy the power structure of the profession, eliminate the power elite that controls the profession through its undemocratic structure, and redefine sociology to correspond to social reality." 110 The SLM soon broke up and reorganized itself into the Radical Caucus, which was not long in splintering into rival sects. Women sociologists formed their own caucus, as did Chicano sociologists, as did gay sociologists, as did black sociologists. Each met in its own convention session, attended its own party, coined its own slogans, and discovered, on its own, that it had more power within the profession, and less influence over it, than any of them hitherto had supposed.

As Mills's epigones carried his legacy into the maelstrom of 1968, the meaning of his biography altered in response to events he could not have been expected to anticipate. He might have accepted his portion of responsibility for the psychodynamics of the New Left before it reorganized into terrorist cells, and the New Man degenerated into the Victim and the Survivor, the representative characters of the 1970s. Before this happened Mills might have regarded the student rebellions as a valuable opportunity to force liberals out of their complacency, to rebuild American colleges and universities as forums for critical thought. As his former student and colleague Immanuel Wallerstein said, "The student revolt has in many ways restored the possibilities for the radical intellectual to rise to his task and find his appropriate place in the movement." Wallerstein, a member of the Ad Hoc Faculty Group at Columbia, co-edited The University Crisis Reader (1971) 
and dedicated it to Mills. ${ }^{111}$

Hofstadter himself was walking with Frank Friedel in front of the library at Columbia not long after the occupation. Freidel, remembering the time they had spent with Mills at the University of Maryland, said it was a shame he had not lived to enjoy the spectacle, for it would have been his glory. Hofstadter disagreed. "He said he could picture Mills standing on the steps of the Low Library calming down the students," Friedel reported, "that Mills would have rather taken a serious view of the efforts to destroy the university and done what he could to rescue it. As I thought about it, I thought he was quite right." 112

Had Mills lived long enough to choose sides, his experimentalism would have seen him through many contingencies, which would have improved his perspective many times by then. All along, his pragmatism would have tempered his exhortations. "Is anything more certain than that in 1970 our situation will be quite different?" he had written in his "Letter to the New Left," where he counselled intellectuals to be "realistic in our utopianism." Most likely, the choice of sides would no longer have been amenable to his definitions. In his independence he had declined to narrow the idea of radical commitment to a false choice between confrontation and withdrawal, yet in Havana, in London, and in New York, these were the only terms on offer by the end of the decade. His legacy torn apart by the very forces he had unleashed, he would have been marooned on noman's-land.

In the opening scene of R.P.M. (Revolutions Per Minutes), a film released by Columbia Pictures in 1970, a group of rabble-rousing college students is occupying the administration building. Apparently the school has endured several confrontations between student radicals and the college administration, each one more bitter than the last. Now a large number of respectable students has joined with the militants, and the militants are refusing to talk to the trustees. Only three men hold their trust: Che Guevara; Eldridge Cleaver; and the school's own professor of sociology, F.W.J. Perez, known locally by his nickname, Paco.

Alone among the adults Paco Perez sympathizes with the radicalism of youth. Played by a broad-shouldered, tough-talking Anthony Quinn, Paco rides a motorcycle to campus. He wears an open shirt to class. He forswears the detached manner of his colleagues, quipping "cool" after he belittles Talcott Parsons in front of students. When the radicals on campus refer to the trustees as "absentee landlords in the ghetto of the mind" he does not object. And when they ask him to join their rally outside a local chemical plant, he agrees. Paco even keeps a young girlfriend, a sociology graduate student played in the film by AnnMargret. The recent intensification of campus conflict, however, has strained his credentials. Paco is now 52 years old (the same age Mills would have been in 1970). A rumor accuses him of being sexually impotent. "I am a fake," Paco says anxiously to his girlfriend, soon after he agrees to mediate the present conflict.

Quickly, disconcertingly, Paco discovers that he is unable to convince the 
militants of the value of dialogue. Turning to address the rank-and-file, he assures them that he understands their anger, yet reminds them that John Dewey, "my spiritual mentor," measured civilization by the efficacy of cooperative intelligence against brute force. The militants, in response to this, threaten to destroy the school's central computer. Paco is thrown into a crisis. He has made his position clear to the trustees at the start: "One thing you never do on a college campus, I mean never, you never call the police." What will he do now?

R.P.M. was produced and directed by Stanley Kramer, which should have been enough to make the movie a success. Kramer believed in cinema as a medium for articulating social conflict. His films included High Noon and The Wild One and Inherit the Wind and Judgment at Nuremberg and Guess Who's Coming to Dinner. But R.P.M. was a commercial and critical bust, the least successful film he ever made. "I was as bewildered as most people by the seething confusion in society," Kramer later explained; the student rebellions had left him "in torment."

Paco Perez felt the same. Caught between rival absolutisms, he decides the conflict is unsolvable, calls the police, and hopes for the best. The students are savaged. The final scene shows Paco walking, eyes lowered, across campus. An angry crowd curses and taunts him, booing him off the stage of history.

\section{NOTES}

1 Print Order Book, Ballantine Books, in my possession.

2 Ian Ballantine to Mills, 5 January 1961.

3 Paperbound Books in Print, v. 7 (Fall 1962): 412.

4 A complete bibliography of published and unpublished writings may be found in The Politics of Truth: Selected Writings of C. Wright Mills, selected and introduced by John H. Summers (New York: Oxford University Press, 2008).

5 http://www.isa-sociology.org/books/vt/bkv 000.htm (Accessed 24 November 2008).

6 See, for example, Kevin Mattson, Intellectuals in Action: The Origins of the New Left and Radical Liberalism, 1945-1970 (University Park, Pennsylvania: Penn State University Press 2002); Michael Denning, The Cultural Front: The Laboring of American Culture in the Twentieth Century (New York: Verso, 1996); Christopher Shannon, Conspicuous Criticism: Tradition, the Individual, and Culture in American Social Thought, Veblen to Mills (Baltimore: Johns Hopkins University Press, 1996); James Miller, 'Democracy Is In The Streets' (New York: Simon and Schuster, 1987); Russell Jacoby, The Last Intellectuals (New York: Basic Books, 1987); and Cornel West, The American Evasion of Philosophy (Madison: University of Wisconsin Press, 1989).

7 See, for example, Arthur Schlesinger Jr., "Who Rules America?" Playboy, September 2004: 47-50.

8 Todd Gitlin, The Intellectuals and the Flag (New York: Columbia University Press, 2006), $1,27$.

9 Richard Rorty, Achieving Our Country (Cambridge, Massachusetts: Harvard University Press, 1998). Rorty did not tell his readers when or why Mills came to his call for a 
"separate peace" between Cold War intellectuals, leaving the false impression that Mills was agitating for neutralism while Stalin still lived. Any attempt to grasp Mills's neutralism has to acknowledge its first premise, namely, that things were changing in communist societies after 1956. In another polemic, Rorty further mangled this history by (mis)attributing the idea of a "separate peace" to Christopher Lasch. See Against Bosses, Against Oligarchies: A Conversation with Richard Rorty, eds. Rorty, Derek Nystam, and Kent Puckett (Chicago: Prickly Paradigm Press, 2002), 50.

10 Robert H. Bork, Slouching Towards Gomorrab: Modern Liberalism and American Decline (New York: Regan Books, 1996), 1.

11 Immanuel Wallerstein, review of .C. Wright Mills: An American Utopian by Irving Louis Horowitz, Theory and Society 15 (1986): 467.

12 See John Summers, “The Epigone's Embrace: Irving Louis Horowitz on C. Wright Mills," Minnesota Review, no. 68 (Spring 2007): 107-124; and John Summers, "NoMan's-Land: C. Wright Mills in England," in Penultimate Adventures with Britannia: Personalities, Politics, and Culture in Britain, edited by William Roger Louis (London: I.B. Tauris, 2008): 185-199.

13 Editorial note, Our Generation Against Nuclear War 1 (Summer 1962): 7.

14 Drafts of the poem may be found in Folder 33, Box 1, Lawrence Ferlinghetti Papers, U.C. Berkeley Bancroft Library, Manuscripts Collection.

15 Edward Abbey, Desert Solitaire: A Season in the Wilderness (New York: Simon and Schuster, 1968), 7.

16 Ralph J. Gleason, "An Epitaph for C. Wright Mills," San Francisco Chronicle, 3 April 1962. Gleason repeated and elaborated his comment on "The Causes of C. Wright Mills," narrated by Landau and Elsa Knight Thompson, broadcast on KPFA radio on 1 October 1962. The recording may be found in Pacifica Radio Archives, number BB0281a-b.

17 Theodore Roszak, The Making of a Counter Culture (Garden City, New York: Doubleday, 1969), 25.

18 Norman Mailer, The Armies of the Night: History as a Novel, the Novel as History (New York: New American Library, 1968), 208.

19 Quoted in "Cuba Mourns Professor Mills," New York Times, 24 March 1962: 25.

20 Politica, 1April 1962.

21 E.P. Thompson, “C. Wright Mills: The Responsible Craftsman,” Peace News, no. 1431 (29 November 1963): 8.

22 E.P. Thompson, “C. Wright Mills: The Responsible Craftsman” Peace News, no. 1430 (22 November 1963): 6. Thompson's Peace News essays were reprinted in slightly different form as "The Responsible Craftsman," Radical America 13 (July-August 1979): 61-73; and again as "Remembering C. Wright Mills" in Thompson, The Heavy Dancers (London: Pantheon, 1985), 261-274.

23 Sociology on Trial, eds. Maurice Stein and Arthur Vidich (Englewood Cliffs, New Jersey: Prentice Hall, 1963). So completely did Mills dominate this movement that The Dissenting Academy, ed. Theodore Roszak (New York: Vintage, 1967) contained no entry for sociology. Mills, Roszak explained in his introduction, had already overthrown the orthodoxy, and no better criticism of sociology could be imagined. For the history of radical sociology, the best volume is Radical Sociologists and the Movement: Experiences, Lessons, and Legacies, eds. Martin Oppenheimer, Martin J. Murray, and 
Rhonda F. Levine (Philadelphia: Temple University Press, 1991); Joseph Scimecca, "Paying Homage to the Father: C. Wright Mills and Radical Sociology" The Sociological Quarterly 17 (Spring 1976): 180-196; and Irving M. Zeitlin, “The Plain

Marxism of C. Wright Mills" in The Revival of American Socialism: Selected Papers of the Socialist Scholars Conference, ed. George Fischer (New York: Oxford University Press, 1971).

24 Alvin W. Gouldner, The Coming Crisis of Western Sociology (New York: Basic Books, 1970), 15.

25 As reported in Robert K. Merton, "Three Fragments from a Sociologist's Notebooks: Establishing the Phenomenon, Specified Ignorance, and Strategic Research Materials," Annual Review of Sociology 13 (1987): 4-6.

26 Dennis H. Wrong, "C. Wright Mills Recalled" in Wrong, Reflections on a Politically Skeptical Era (New Brunswick, New Jersey: Transaction, 2004), 166. Rumours that Mills had not received a decent obituary from the sociology profession also were unfounded. See the notices in the American Sociological Review 27 (1962): 579-580; and American Journal of Sociology 68 (1962): 105-107.

27 See, for example, Dusky Lee Smith, "The Sunshine Boys," in Radical Sociology, eds. J. David Colfax and Jack L. Roach (New York: Basic Books, 1971), 28-44.

28 Dusky Smith to Mrs. Mills, 5 July 1965. C. Wright Mills Papers, University of Texas.

29 Gil Green, "Marxism and C. Wright Mills" Political Affairs 42 (September 1963): 29.

30 Jonah Raskin, email to author, 13 July 2006.

31 Personal interview with Morton Horwitz, 6 March 2006.

32 Stokely Carmichael, with Ekwueme Michael Thelwell, Ready for Revolution (New York, Scibner: 2003), 131.

33 Jack Newfield, A Prophetic Minority (New York: New American Library, 1966), 107.

34 Harold Cruse, The Crisis of the Negro Intellectual (New York: Morrow, 1967), 466-467. Also see Van Gosse, "Locating the Black Intellectual: An Interview with Harold Cruse" Radical History Review 71 (Spring 1998): 115; and Harold Cruse's The Crisis of the Negro Intellectual Reconsidered, ed. Jerry Watts (New York: Routledge, 2004).

35 Cruse, Crisis, 459, 467.

36 Zaid, email to author, 18 March 2006.

37 Abbie Hoffman, Soon to be a Major Motion Picture (New York: Putnam, 1980), 87.

38 Christopher Lasch, The New Radicalism in America, 1889-1963 (New York: Vintage, 1967), 336.

39 Dave Meggyesy, Out of Their League (Berkeley: Ramparts Press, 1970), 176.

40 Robert Lipsyte, "First, Get Your Head Together," New York Times 19 May 1969: 62.

41 On Mills's influence in SDS, see James Miller, "Democracy is in the Streets': From Port Huron to The Siege of Chicago (New York: Simon and Schuster, 1987); Kirpatrick Sale, SDS (New York: Random House, 1973), 36, 42, 49, 338; and Andrew Jamison and Ron Eyerman, Seeds of the Sixties (Berkeley: University of California Press, 1994), 30 46.

42 Mills, Sociological Imagination, 8.

43 Todd Gitlin, email to author, 2 November 2006.

44 Ibid.

45 Gitlin, "Can We Trust the Russians?" The Tocsin, 16 December 1960: 1-3; Gitlin, "Deterrence and Reality," Tocsin Forum 3 (October 1962): 3-12; Gitlin, "Afterword" to 
C. Wright Mills, The Sociological Imagination (New York: Oxford University Press, 2000 [1959]); Gitlin, "The Battlefields and the War" in The New Student Left, eds. Mitchell Cohen and Dennis Hale (Boston, Beacon: 1966), 120-131; Gitlin, "The Limits of Defense" New University of Thought 2 (Spring 1962): 43-51; Gitlin, "Mills the Cat," Liberation 11 (March 1966): 11; Gitlin, The Sixties: Years of Hope, Days of Rage (New York: Bantam Books, 1987), 87, 89; Gitlin, "Local Pluralism as Theory and Ideology" Studies on the Left 5 (Summer 1965): 21-45; and Gitlin, "Power and the Myth of Progress," in The New Left: A Documentary History, ed. Massimo Teodori (London: Jonathan Cape, 1969), 172-182. In 1978, Gitlin published a pathbreaking, Millsian critique of Katz and Lazarsfeld's Personal Influence. See Gitlin, "Media Sociology: The Dominant Paradigm," Theory and Society 6 (September 1978): 205-253.

46 Richard Flacks, Conformity, Resistance, and Self-Determination: The Individual and Authority (Boston: Little, Brown, 1973), 12. Also see Richard Flacks, "Making History vs. Making Life: Dilemmas of an American Left" in Toward a History of the New Left: Essays from Within the Movement, ed. R. David Myers (Brooklyn, New York: Carlson Publishing, 1989), 125-152; Richard Flacks, Making History: The American Left and the American Mind (New York: Columbia University Press, 1988).

47 Robert J.S. Ross, "At the Center and the Edge: Notes on a Life in and out of Sociology and the New Left" in Radical Sociologists and the Movement: Experiences, Lessons, and Legacies, eds. Martin Oppenheimer, Martin J. Murray, and Rhonda F. Levine ,197; and an earlier version in Critical Sociology 15 (1988): 79; and A. Javier Trevino and Robert J.S. Ross, "The Influence of C. Wright Mills on Students for a Democratic Society: An Interview with Bob Ross," Humanity and Society 22 (August 1998): 260277.

48 Ross, "At the Center and the Edge," in Radical Sociologists and the Movement, eds. Oppenheimer, Murray, and Levine, 197-215.

49 Tom Hayden, Reunion: A Memoir (New York: Random House, 1988), 80.

50 Thomas Hayden, "A Letter to the New (Young) Left" in The New Student Left, eds. Mitchell Cohen and Dennis Hale, 120-131.

51 Hayden, Reunion, 42.

52 Tom Hayden, Radical Nomad: C. Wright Mills and His Times (Boulder, Colorado Paradigm, 2006 [1964]), 69.

53 Hayden, Reunion, 86.

54 Hayden, Radical Nomad, 70.

55 Ibid., 58.

56 Newfield, 120-121.

57 United States Senate, Committee on the Judiciary, Castro's Network in the United States (Fair Play for Cuba Committee) 88th Cong, 1st Sess., Part 3 (Washington: GPO, 1963), 185.

58 “Anti-American Attitudes: A Symposium," Listener 67 (19 April 1962): 667-668.

59 Arnold M. Rose, The Power Structure (New York: Oxford University Press, 1967), xvii.

60 Irving Howe, "On the Career and Example of C. Wright Mills," in Howe, Steady Work: Essays in the Politics of Democratic Radicalism, 1953-1966 (New York: Harcourt, Brace \& World, 1966), 252. Also see Beyond the New Left, ed. Irving Howe (New York: McCall, 1970); and Maurice Isserman, If I Had a Hammer: The Decline of the Old Left and the Birth of the New Left (New York: Basic Books, 1987), 118-120.

61 Interview with Charles Frankel, 29 April 1964, Newsweek. Archives, Box 282, Center for 
American History, University of Texas, Austin.

62 Edward Shils, "The Obsession," The Spectator, no. 7045 (5 July 1963): 20.

63 Edward Shils, "Professor Mills on The Calling of Sociology," World Politics 13 (July 1961): 621.

64 Shils, "The Obsession" 21. On Shils's attitudes toward Vietnam and campus politics, see Shils, "Higher Education in Industrial Societies" in Stephen R. Graubard and Geno A. Ballotti, eds., The Embattled University (New York: George Braziller, 1970), 430; and Shils, "Totalitarians and Antinomies" in Political Passages, ed. John H. Bunzel (New York: The Free Press, 1988), 19.

65 From the original 1948 edition book jacket.

66 For example: In 1960, he praised Bell's The End of Ideology on the grounds that "He destroys the power-elite thesis of C. Wright Mills." Arthur Schlesinger Jr., "In the American Fashion," New York Times Book Review 3 April 1960: BR33.

67 Schlesinger, Letter to the Editor, New York Times 1 July 1962: 137.

68 As reported in William F. Buckley, Jr., "Why No Fuss Over the Irresponsible Left?" Los Angeles Times, 29 April 1962: F6. An essay by Denis Brogan in the Times Literary Supplement, complained in this same vein. Mills "appeals to the same conspiratorial tastes on the left as do the theories of the John Birch Society on the right. His diagnosis is fundamentally passive and pessimistic." Dennis Brogan, "Spooks of the Power Elite," Times Literary Supplement 17 August 1967: 736.

69 Mills, Listen Again Yankee, 27.

70 Mills, "Letter to Spain," unpublished essay in my possession.

71 Arthur Schlesinger Jr., A Thousand Days: John Kennedy in the White House (Boston, 1965), 206. Privately, Schlesinger declared himself “anti-Mills.” Arthur M. Schlesinger Jr. Interview (\#914), Richard Hofstader Project, Oral History Research Office, Columbia University, 1973, 5.

72 Port Huron Statement, in Miller, Democracy in Streets, 344.

73 SDS, "America and the New Era," in The New Left: A Documentary History, ed. Massimo Teodori , 177, 178.

74 Ibid., 173.

75 As quoted in Jean Daniel, "Unofficial Envoy: An Historic Report from Two Capitols," The New Republic 149 (14 December 1963): 16.

76 Dan Wakefield, “Taking It Big: A Memoir of C. Wright Mills," Atlantic Monthly 228 (September 1971): 70.

77 Mills, "The Decline of the Left".

78 Mills and Landau, "The House That Jack Must Build: Modest Proposals for Patriotic Americans" London Tribune, 19 May 1961: 5.

79 Saul Landau, "From the Labor Youth League to the Cuban Revolution," in History and the New Left: Madison, Wisconsin, 1950-1970, ed. Paul Buhle (Philadelphia, Temple University Press: 1990), 110, 112.

80 Saul Landau, “C. Wright Mills: The Last Six Months” Ramparts (August 1965): 46-54. Also published in Root and Branch, no. 2. "The Causes of C. Wright Mills," narrated by Landau and Elsa Knight Thompson, was recorded on 7 September and broadcast on KPFA radio on 1 October 1962. The recording may be found in Pacifica Radio Archives, number BB0281a-b.

81 The quotations in this paragraph come from Ralph Miliband, "C. Wright Mills" New 
Left Review (May-June 1962): 19, 17. Also see Miliband's short essay in British Journal of Sociology 15 (March 1964): 78-79; and Miliband, "Mills and Politics," in The New Sociology, ed. Irving Louis Horowitz (New York: Oxford Universiy Press, 1964), 76-87.

82 Miliband, “C. Wright Mills," Dissent 10 (Summer 1963): 296.

83 As quoted in Michael Newman, Ralph Miliband and the Politics of the New Left (London: Merlin Press, 2002), 67.

84 Mills, The New Left, 8.13.

85 Mills, "Who I Am and How I Got To Be That Way" (1957) unpub manuscript, pages "Five b."

86 Mills, New Left, 8.11

87 Mills, New Left, unpaginated fragment.

88 Except where noted the next few paragraphs rest on H. Gordon Skilling, Crechoslovakia's Interrupted Revolution (Princeton: Princeton University Press, 1976); J. Klofáã and V. Tlusť, Soudobá Sociologie (Prague, 1965); and Vladimir Kusin, The Intellectual Origins of the Prague Spring (Cambridge: University Press, 1971).

89 Miroslav Jodl, "The Humanist Sociologist," introduction to C. Wright Mills, Mocenskea Elita, trans. Jodl (Prague, 1966). I am indebted to Michal Labik, a student of mine at Harvard, for translating Jodl's introduction into English.

90 Ivan Sviták, "The Consequences of Words" as reprinted in Ivan Sviták, The Crechoslovak Experiment, 1968-1969 (New York: Columbia University Press, 1971): 121

91 Ivan Sviták, "Ten Commandments for an Adult Intellectual" and it appeared in the weekly magazine in Prague, in July 1968 as reprinted in Sviták, The Czechoslovak Experiment, 112. For background see Ivan Sviták, "Intellectuals and Workers in Czechoslovak Democratization” New Politics 7 (Spring 1968): 50-59; and Sviták, "Letter to Prague Lawyer," New Politics 9 (Winter 1972): 68-69.

92 "With Your Head Against the Wall," in Winter in Prague: Documents on Czechoslovak Communism in Crisis, ed. Robin Alison Remington (Cambridge: M.I.T. Press, 1969), 80.

93 Todd Gitlin, "The Texture of the Cuban Revolution," New Left Notes 3 (12 February 1968): 4-6; and Gitlin, "Cuba and the American Movement," Liberation 13 (March 1968): 17, 13.

94 K.S. Karol, Guerrillas in Power: The Course of the Cuban Revolution, trans. Arnold Pomerans (New York: Hill \& Wang, 1970), 11.

95 Personal Interview with K.S. Karol in Paris, 13 November 2004.

96 Karol, Guerrillas in Power, trans. Pomerans, 10.

97 Ibid., 271.

98 In addition to the sources listed below, I have followed Robert A. McCaughey, Stand, Columbia: A History of Columbia University in the City of New York, 1754-2004 (New York: Columbia University Press, 2003), 427-461; Stephen Spender, The Year of the Young Rebels (New York: Random House, 1968), 1-36.

99 Richard Hofstadter, "The Columbia University Commencement Address for the 214th Academic Year," 4 June 1968, pamphlet in my possession.

100 Who Rules Columbia?, 10, 11.

101 Personal interview with Michael Klare, 10 July 2006.

102 Staughton Lynd and Thomas Hayden, The Other Side (New York: New American Library, 1966), 219.

103 Tom Hayden, “Two, Three, Many Columbias,” Ramparts 6 (15 June 1968): 40. SDS’s 
official statement on the occupation, adopted 12 September 1968, echoed the logic of equivalence in Hayden's essay. "If the Vietnamese could withstand the force of bombs, if the Blacks could withstand the onslaught of modern police, if Cubans could triumph over Imperialism, could we not also, in some tiny way, join the struggle for liberation? We thought we could." See "The Columbia Statement" as reprinted in The University Crisis Reader, Volume 1: The Liberal University Under Attack, eds. Immanuel Wallerstein and Paul Starr (New York: Random House, 1971), 23-31.

104 Lionel Trilling, "Interview," Partisan Review 35 (Summer 1968): 391.

105 Daniel Bell, "Columbia and the New Left," The Public Interest, no. 13 (Fall 1968): 62, 100-101.

106 David S. Brown shows Hofstadter's “intellectual confusion over how to response to the New Left" in the final chapters of Richard Hofstadter: An Intellectual Biography (Chicago: University of Chicago Press, 2006). See page 194 for the quotation and page 226 for the comment to Newsweek.

107 Arthur Schlesinger, Jr., The Imperial Presidency (Boston: Houghton Mifflin, 1973), 408.

108 Tom Hayden, “Two, Three, Many Columbias,” Ramparts 6 (15 June 1968), 40.

109 Martin Nicolaus, "Fat-Cat Sociology," as reprinted in R adical Sociologists and the Movement, eds. Oppenheimer, Murray, and Levine, 251-254. Quotation on page 253. Also see Dick Flacks, "The Sociology Liberation Movement: Some Legacies and Lessons" in Radical Sociologists and the Movement, 17-27.

110 Martin Oppenheimer, Martin J. Murray, and Rhonda F. Levine, “The Movement and the Academy" in Radical Sociologists and the Movement, 9.

111 Immanuel Wallerstein, "Radical Intellectuals in a Liberal Society," reprinted in The University Crisis Reader, Volume 2: Confrontation and Counterattack, eds. Immanuel Wallerstein and Paul Starr (New York: Random House, 1971), 477.

112 Frank Freidel Interview (\#939), Richard Hofstader Project, Oral History Research Office, Columbia University, 1973; 10. 